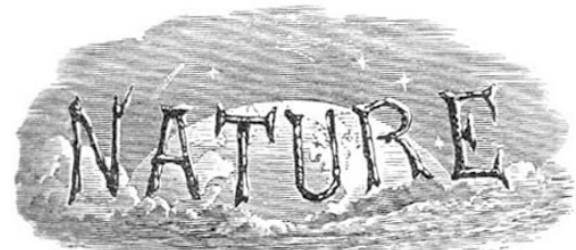

SATURDAY, OCTOBER I8, I924.

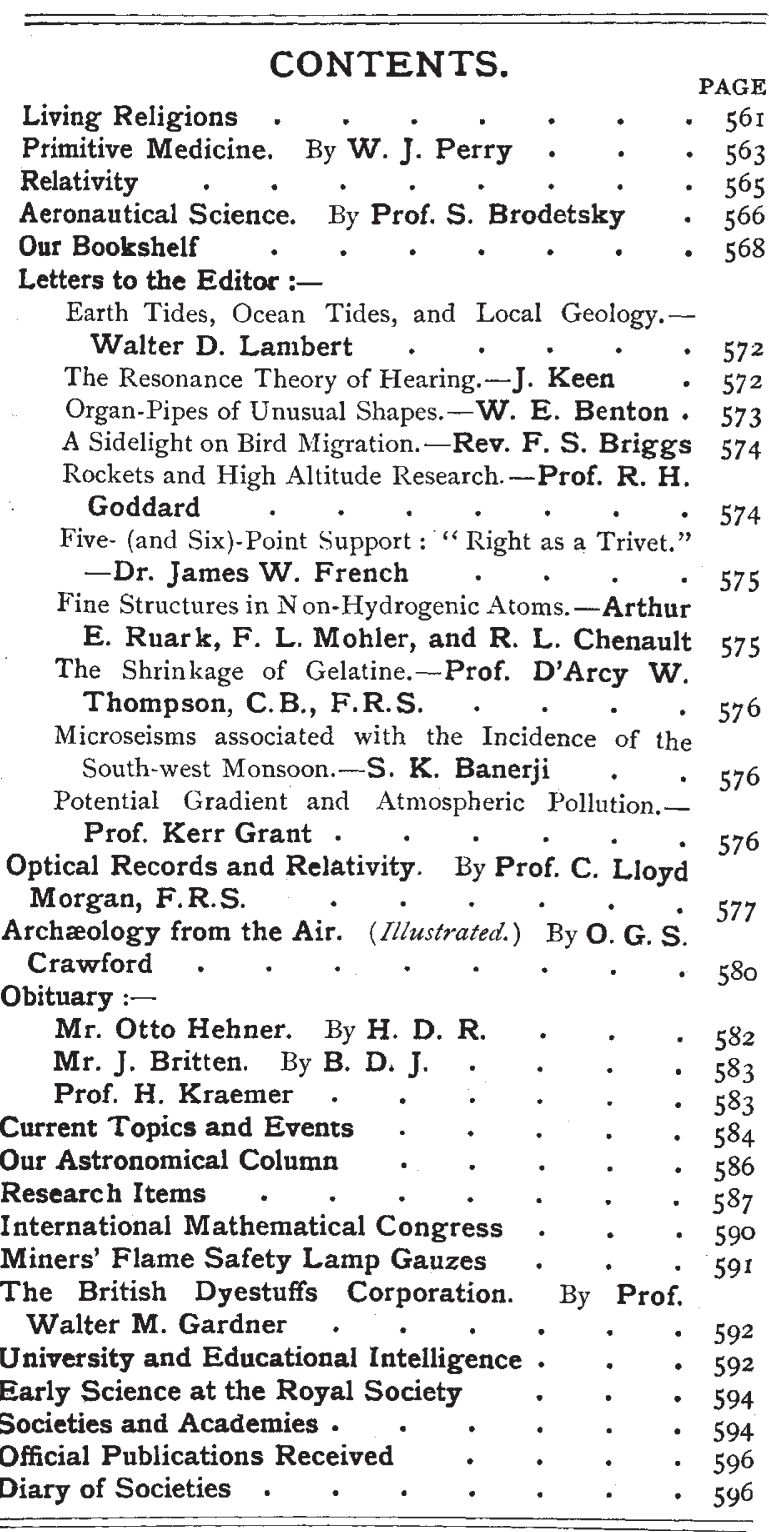

Editorial and Publishing Offices:

MACMILLAN \& CO., LTD.,

ST. MARTIN'S STREET, LONDON, W.C. 2.

Editorial communications should be addressed to the Editor. Advertisements and business letters to the Publishers.

Telephone Number: GERRARD 8830.

Telegraphic Address: PHUSIS, WESTRAND, LONDON.

\section{Living Religions.}

FoR nearly two weeks-from September 22 to October 3-a Conference has sat in London to listen to the tenets of some of the principal living religions of the world as expounded by distinguished adherents. It was held on the initiative of the School of Oriental Studies and the Sociological Society. The Conference, it is believed, was the first of its kind and was intended primarily to be educative It aimed both at disseminating accurate information relating to the religions represented and at removing certain popular misunderstandings. Mohammedanism, Hinduism, Buddhism, Taoism, the religion of Sikhs, Jains and Parsis, and primitive religions were represented, for the most part by members of the British Empire. It thus affords some indication, imperfect perhaps, of the great variety of religious belief to be found within this one political organisation.

An exposition of religious dogma at a conference carries with it something of an academic atmosphere, and, however much it may bring out the contrasts of different systems of religious philosophy, it fails to give full emphasis to their moulding force in determining the practical attitude of those who profess them towards their fellow-men and towards life as a whole. The influence of religion may appear imponderable except in times of conflict and stress. Life in a modern community does, no doubt, obscure it, may even weaken it ; but for the majority of the inhabitants of the world, it is still all-pervasive and fundamental. This is more especially evident in the case of primitive peoples. It is on this account that study of primitive belief and ritual is an essential precedent condition of success in the administration of backward races.

It is not without significance that the religions of India should have taken a prominent place in the proceedings of the Conference. They rest upon a highly developed theologicaland philosophical basis; they present marked contrasts ; and perhaps nowhere else is it possible to see more clearly the force of religious belief in determining the form and character of social organisation. In Hinduism the system of caste, with its rigid determination of social grades, the doctrine of asceticism, and the emphasis laid upon meditation as a form of religious practice, permeate every phase of Hindu society. The caste divisions, with the doctrine of untouchables and the specialisation of occupation, have proved, and are likely to continue to prove, an insurmountable obstacle to any lasting social and political unity. They have given a static character to social organisation which stands in the way of development.

The effect of religious belief, however, in the daily life of the people is even more clearly to be discerned when attention is directed to primitive conceptions, not

NO. 2868, VOL. I I 4 ] 
merely as they appear enshrined as survivals in the highly developed philosophical thought of official Hinduism, but in the popular religion, the traditional animistic beliefs, and the regard for the village deities of the mass of the population which were overwhelmed with the Aryan invasion but are still the predominant element in the popular religion. The significance of the survival of these primitive forms of belief lies in the fact that they still tend to keep alive the village community as the effective social unit. It is noteworthy that the modernist movements in India, which aim at a larger unity, seek to break down what, from the social if not from the philosophical point of view, have been the most persistent features in Hinduism. The reform movements in Hinduism, therefore, both BrahmoSamaj, with its tendency toward universalism in its later developments, and Arya Samaj, with its militant nationalism, aim at ignoring differences of race and caste and seek to mould India into one people. In the same way the differences in doctrine of other forms of religion, whether Mohammedan, Parsi, Sikh, or Jain, are reflected in their social organisation. Yet if they neither observe caste nor practise asceticism in the strict sense of the term, they do not any the less hold themselves strictly apart. How deep is the line of cleavage can be seen in the bitterness of the conflict between Hindu and Moslem, which is repeatedly manifested upon occasions which might seem trivial to an outside observer. At the present moment the attempt at a reconciliation between the two bodies hangs upon an adjustment of their respective attitudes towards the cow, and whether it may be possible for the Mohammedans to devise a method of slaughter of this sacred animal which will not offend the susceptibilities of the Hindu.

The philosophical character of the sacred books, and the fact that information relating to Indian religion has been too exclusively drawn from literary sources, has tended to obscure the practical effect of religious belief in determining the form of Indian social institutions except in their more obvious aspects. But none the less in India, as in other parts of the world where religious beliefs conform to a primitive type, that attitude towards the hidden powers underlying material things which anthropologists call animism is a dominant factor in the form and content of social life. An instance at once suggests itself. The social organisation of the Todas depends entirely upon the sacred character of the cow ; it is arranged to meet the requirements of the ritual of the dairy. An analogous case is to be found in East Africa, where the institution of royalty and the whole of the kingly ceremonial among the Bahima is based upon the sacred nature of the cattle and the dependence of their welfare upon the king. Even the diet of the people and their food taboos, NO. 2868 , vOL. I I 4 ] whether temporary or permanent, are related to the sacrosanctity of the milk and the care which must be taken to protect it from the slightest danger of ritual uncleanness.

It would be possible to add almost innumerable instances among primitive peoples in which the form and content of social institutions are directly dependent upon the character of their religious beliefs. The widely spread totemic system in its various types, the matriarchate and the prominence given to the mother's brother in all matters in which in the patriarchal system the father holds the authority, are instances striking by their diversity from our own customs. But, as Sir James Frazer has shown in "Psyche's Task" (London: Macmillan and Co.), primitive religious ideas underlie some of the most important functions of modern civilised life. Taboos similar to those which are now observed in the islands of the Pacific lie deep rooted at the base of our ideas of property; the divine right of kings can trace its ancestry to the sacred character of the chief, whose power may rest either with the fact that he embodies the spirits of his ancestors, or that by his power as a magician he can control the hidden forces of the world around. The primitive belief in magic has determined the forms of the law, and the invocation of spirits, assisted by the administration of poison or other form of test, has grown into the trial by ordeal out of which our judicial procedure has developed, still retaining the administration of the oath, formerly a test and now a guarantee of the honesty of a witness.

It may be asked in what sense the term "living religions" has been applied in selecting the forms of religious belief to come before the Conference which has just been held. An attempt to supply an answer to the question has been made by Mr. Victor Branford in an essay ${ }^{1}$ which, although not an official publication, was issued as an interpretative study a few days before the Conference met. Mr. Branford, who is a co-worker with Prof. Patrick Geddes, would apply the term only to those religions which show signs of developing along the lines of the larger modernism. As an instance of his meaning he cites the case of Indore, where the ritual processions have been adapted, at the suggestion of Prof. Geddes, to subserve the needs of the city in improved sanitation and housing. In the modern State, he beholds a vision of a cult in which the complete unification of the sciences and arts is directed to the cultivation of the highest faculties in man in a civic environment in perfect harmony with that end. There perhaps the matter may be left without too close an examination of how far the place of religion in an actual modern community falls short of this ideal.

1 "Living Religions: a Plea for the Larger Modernism." By Victor Branford. Pp. xxxvi +290 . (London: Leplay House; Williams and Norgate; r924.) 5 s, net. 